\title{
Cara-Cara Menentukan Kekunaan Gerabah Dalam Penelitian Arkeologi: Analisis Eksternal
}

\section{Goenadi Nitihaminoto}

Keywords: artefacts, ceramics, pottery, analysis, methods

\section{How to Cite:}

Nitihaminoto, G. (1993). Cara-Cara Menentukan Kekunaan Gerabah Dalam Penelitian Arkeologi: Analisis Eksternal. Berkala Arkeologi, 13(1), 66-76. https://doi.org/10.30883/jba.v13i1.566

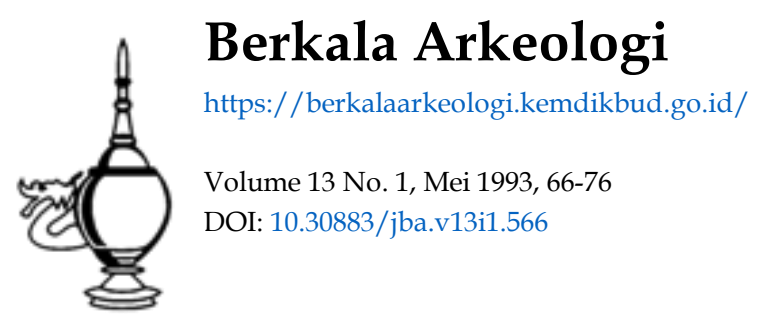


Cara-Cara Menentukan Kekunaan Gerabah Dalam Penelitian Arkeologi: Analisis Eksternal

Oleh: Goenadl Nethaminoto

Studi tentang keramlk selama Inl sangat menarlk perhatian di kalangan para arkeolog Indonesla. Keramlk merupakan data arkeologl yang terbuat dar tanah llat. Jenls-jenls keramlk berdasarkan perbedaan tingkat pembakarannya dibedakan menjadi dua Jenis yaltu porselin-batuan dan gerabah, sedangkan berdasarkan fungsinya terbagl darl wadah dan non wadah. Dalam penulisan inl pembahasan akan ditttkbetakkan pada gerabah. Tanah liat sebagal bahan pembuatan gerabah mempunyal sifat plastls dan sifat inl akan hilang apabila dibakar sehingga gerabah tidak mudah basah (Samldi. 1982:71). Pecahan gerabah disebut kereweng. Kedua Istllah itu berasal dart Jawa yang eampal saat InI masth dipakal oleh beberapa peneliti. Selama Inl dalam penyebutan istllah tersebut belum dibedakan tentang segi kekunaannya, sehingga dalam menganalisis tingkat kekunaannya maslh sering tercampur antara gerabah kuna dengan gerabah baru.

Dalam penulisan inl gerabah dibedakan pengertian antara kereweng kuna, resen (recent), dan baru Resen dan baru mempunyal pengertian yang sama, namun dalam tulisan inl dibedakan untuk memudahkan pengertian dan penyebutan. Kreweng kuna yaltu kreweng yang telah berumur ratusan atau ribuan tahun dengan cir-cirl fisik tertentu.

Kreweng resen untuk menyebut kreweng baru yang sudah tIdak baru lagi dan tidak kuna. sebaglan kecll gerabahnya masth digunakan karena warlsan. Kreweng resen dindingnya tampak agak pudar dan gerabahnya Jarang blasanya terletak agak Jauh atau dekat dar perumahan penduduk. Gerabah resen umurnya leblh tua daripada gerabah baru dan diperkdrakan telah berumur antara 10 50 tahun. Pembatasan umur sampal dengan < 50 tahun didasarkan pada daya tahan gerabah misalnya misalnya untuk menyimpan bij1biflan yang hanya dlambll setahun sekall. Karena penakalannya yang farang terangkat atau tersentuh mungkin dapat bertahan 
sampal 50 tahun. Singkatnya gerabah resen adalah gerabah yang umurnya di antara gerabah baru dan gerabah kuna.

Kereweng baru dimaksudkan untuk kreweng yang gerabahnya masth dipakal. Kreweng baru blasanya mempunyal dinding yang relatif segar dan tanda-tanda bekas pakalnya masth tampak Jelas. Kreweng Jenis tni blasamya terletak di dalam pekarangan penduduk atau tak begitu Jauh dart perumahan itu dan umurnya diperkirakan sekJtar 0 - 20 tahum. Pembatasan umur gerabah baru didasarkan pada ketahanan gerabah dalam pemakalannya sepertl halnya gerabah resen. Oleh karena itu gerabah baru yang frekuensi pemakalannya tinggi. diperkirakan dapat bertahan lebih paling lama 20 tahun. Dasar klasiflkasi tingkat ketuaan gerabah inl masth lemah sehingga dapat berubah sewaktuwaktu apablla ada alasan yang leblh kuat.

Kreweng yang ditemukan sering bercampur baur antara kreweng kuna dan kreweng yang leblh muda. Percampuran In! sering menimbulkan keraguan dalam identiflkasinya, karena sukar dibedakan antara kreweng kuna dan kreweng yang leblh muda. Percampuran kreweng itu disebabkan oleh beberapa aktivitas yang maslh berlangsung antara laln permukiman, pertanlan, ekcnoml, dan upacara ritual.

Adanya percampuran kreweng itu jarang diperhatikan. sehingga serting terjadi bahwa semua kreweng yang telah dikumpulkan dalam penelitian dianggap sebagal kreweng kuna. Apabila hal ini terjadi maka akan mempengaruhi validitas kesimpulan. Sementara itu ada anggapan bahwa gerabah merupakan temuan yang kurang penting sehingga tidak perlu dianalisis secara slstematis. Pada hakekatnya gerabah mempunyal nulai penting yang sejajar dengan temuan-temuan lain. bahkan suatu ketika gerabah merupakan termuan yang spektakuler

Gerabah mernang merupakan artefak penting dalam kehidupan manusla. karena keberadaannya Mdak dapat diplsahkan dengan kehidupan manusla. Hubungan erat Inl tercermin pada fungsinya yang dapat dipakal untuk memenuhi kebutuhan hidup manusla dalam hal makan, dan tempat tinggal (teknofak), dan untuk memenuhl kebutuhan rohantah (Ideofak). Bentuk gerabah Juga erat hubungannya dengan fungsl. karena fungs adalah salah satu faktor penentu penting dart bentuknya. fungsl gerabah dapat dibedakan menjadi gerabah praktis dan gerabah seremonlal. Bentuk gerabah 
yang lebth nimtt dhubungtan dengan kegtatan upacara, cedangkan gerabah dengan bentuk eederhana dihubungkan dengan kepertuan seharl-hart. Gerabah yang ditemukan di dalam kubur dapat dipandøng cebagal perlengtopan ritual yang dipergunakan dalam upacara-upacara penguburan (Sharer RJ dan Windy Aohmore. 1979:316).

Perbedaan fungsi masing-masing akan mempunyal korelasi positif dengan komposisi bahan oerta teknlk pembuatan (BInford,1962:217-225). Mempelajarl gerabah dapat digunakan untuk merekonstruksl gerak-gerlk manusla (Solhelm II, 1964:360-408), sedangkan penelitlan aspek fungsi gerabah dapat mengungkapkan struktur masyarakatnya. yaltu blla gerabah digunakan sebagal wadah kubur. Sistem penguburan merupakan data penting untuk mengetahul kehidupan manuslanya antara religl, teknologl, dan struktur sosial.

Sehubungan dengan art penting Itu, maka banyak dilakukan usaha untuk analists gerabah leblh slstematis. Berbagal analisis yang pernah dilakukan antara lain dengan metode thermoluminessence, untuk menentukan pertanggalan internal untuk mengetahul komposisl bahan dan fungsinya, serta untuk melacak tempat pembuatannya. dan analisis eksternal untuk memperkirakan fungsi, kualitas, dan teknologinya. Meskdpun analisis gerabah telah banyak dilakukan, tetapi dalam kesempatan Inl Ingin disumbangkan salah satu analisls eksternal, untuk membantu para penelitl dalam memberikan Identifkasl tentang kekunaan gerabah.

Adanya kenyataan bahwa sering terjadi percampuran antara kreweng kuna, resen, dan baru, apablla tidak dilmbangl dengan cara analisis tertentu tidak dapat ditentukan secara mantap. sehingga terjadl salah tafsir misalnya kreweng kuna dianggap resen, kreweng resen atau baru dianggap kuna, dan bahkan dapat terjadi seballknya. Apabila terjadi kekurangmantapan dalam memleahkan kreweng kuna dan kreweng yang lebth muda maka akan mempengaruhl hasll analisls. Hasll analisls akan mempengaruhi kualitas penafsiran. dan selanjutnya kesimpulan yang dibertkan kurang valid. 
Pacia umumnya gerabah mempunyal ctri-cirt yang dapat difadikan petunjuk untuk menentukan kekunaannya. Cirl-cirl itu antara lain berasal dart (1) teknologi pembuatan, (2) kualitas, dan (3) patinasi.ditinggalkan pada waktu gerabah dalam proses pembuatan. Metode pembuatan yang telah berlangsung beberapa ratus atau beberapa ribu tahun seringkall masth digunakan oleh penduduk sampal sekarang. sehingga gerabah baru mirip dengan gerabah kuna. Balk pada masa prasjarah maupun pada masa sekarang teknologi pembuatan gerabah mash banyak ditemukan persamaanmya.

Pertama teknologi pembuatan gerabah pada masa prasejarah terdapat 4 metode yaltu metode tangan. metode lingkaran. metode roda putaran, dan metode cetakan (Childe. 1956:120). Metode tangan (hand made) menghastlkan gerabah yang kasar, tebal, dan tidak simetris, karena dalam pembuatannya hampir tddak menggunakan peralatan kecuali tangan dan peraiatan bantu laln yang sangat sederhana. Metode pembuatan gerabah dengan metode tangan Inl sekarang masth dapat diljumpal di beberapa tempat di Indonesla antara lain di Jawa Barat (Nles Anggraent. 1976). Màluku Utara (Wanda Heralre. 1984), di Pulau Bawean (Goenadi Nh. 1988). Nusa Tenggara Tmur (Sumljats As, 1983), dan Irlan Jaya (Goenadi Nh. 1980).

Pembuatan gerabah dengan metode lingkaran (colling) dilakukan dengan membuatan pita darl lanah liat kemudian ditumpuk melingkar, makn lama makdn tungg! hingga mencapal ukuran yang dikehendakd, kemudian kedua telapak tangan ditekankan pada dinding bagian luar dan dalam untuk menipiskan dinding gerabah dan akhimya diselesalkan sesual dengan bentuk yang dikehendakl. Hastl pembuatan gerabah dengan metode lingkaran inl menghasilkan gerabah yang berukuran besar dengan bentuk tidak almetris (Chllde, 1956: 121). Pembuatan gerabah dengan metode tni thdak banyak dijumpal di Indonesia, antara latn di Pulau Adonora. Floreo Timur yang menghasilkan gerabah berukuran kecll (Informasi dart Sumilyatl AB).

Pembuatan gerabah dengan metode roda putaran (potter's wheel menghasllkan gerabah yang lebth halus dan memberikan havll yang leblh banyals (FH Norton, 1856:85). Pembuatan gerabah 
dengan metode inl sekarang leblh banyak dijumpal di beberapa tempat di Indonesla, antara lain di Jawa. Balı (Goenadi Nh, 1971). dan Sumatera (Bennet Bronson et.al. 1973).

Pembuatan gerabah dengan metode cetakan memberikan hasil yang leblh bagus. Cetakan yang dipergunakan dibagi menjadi dua tangkup atau leblh, bagtan yang menonjol dalam cetakan itu memberlkan hasll seballknya pada gerabah. Metode pembuatan gerabah Int sekarang masih dijumpal di daerah Malo. Bojonegoro (Goenadi Nh, 1971).

Cirı teknologi lain dari gerabah kuna lalah bentuk. dan hlasan. Bentuk gerabah kuna sangat sederhana, dan tidak banyak varlasi blbimya. Bentuk baglan dasar pada umumnya bulat. tetapl ada yang runcing. sedangkan bentuk blbirnya sederhana yaitu melipat keluar dan bahkan sampal melengkung ke bawah. Umuinnya kendi kuna berleher panjang. posisı blbir tegak dan rata. bentuk dasar bulat tanpa cerat Bentuk kendi semacam InI masih ditemukan pada produk sekarang, dinamakan kendl gogok

Hlasan gerabah kuna blasanya terdirl darl hlas tera dan gores, dengan beberapa motif. Hlasan paling kuna berupa tera tatap berbalut tall, dan hlas gores pada umumnya menggunakan motif geometris seperti lingkaran, segitiga, dan garis sejajar Meskipun demiklan hlas tera tatap berbalut talı masth dipakal dan diproduksi oleh penduduk Kampung Baringin. Kecamatan Siplrok, Tapanuli Selatan (Bennet Bronson. et.al, 1973:38).

Kedua kualitas, cirl gerabah kuna pada umumnya dapat dikenalı antara laln darı warna. tingkat kekerasan. dan porositasnya. Meskjpun cirt-cirt itu dimllikd Juga oleh gerabah baru dan resen. Warna merah pada umumnya diperoleh darl calran yang terbuat dari tanah atau oker, kemudian dioleskan pada baglan luar dinding gerabah sebelum dibakar Warna merah dapat timbul dart laplean halus yang terbuat dart tanah (coating). yang dioleskan pada dinding gerabah sebelum pembakaran selain itu warna merah sering muncul darl has If pembakaran dengan temperatur tingg1. Maken tinggl suhu pembakarannya makin merah warna yang diakibatkan. Warna merah muncul pula dart penampang lintang dinding yang dapat dillhat pada kreweng. Kecuall wama. kreweng kuna dapat dikenall darl tingkat kekerasan dindingnya. sebagal hasil pembakaran dalam suhu yang leblh tinggi. Tingkat kekerasan tingg1 berkaltan dengan tingkat porositas yaltu makin tinggi 
kekerasannya, tingkat porositasnya semakdn kecll, sehingga dapat diperkirakan fungsinya.

Semua unsur teknologi yang dluralkan di atas akan mengalami perubahan blla gerabah terpendam dalam tanah beberapa waktu lamanya. Blasanya warna menjadi pudar, tingkat kekerasan berkurang dan akh!nya menjadi rapuh, bahkan sering mengalami proses patinast.

Ketiga Pattnas!, artefak masa stlam mengalam! proses perjalanan panjang ya!tu mulal darı saat dibuat, dipakal dan dibuang untuk selanjutnya terpendam dalam tanah sampal akhirnya ditemukan kembali. Dalam proses tersebut artefak mengalami perpindahan tempat, perubahan bentuk, pengurangan atau penambahan jumlah. dan pertukaran hubungan antara satu dengan lainnya (Moendardjito, 1982:500; MB Schiffer. 1976).Pada waktu terpendam dalam tanah kreweng sering mengalami proses khemis, sehingga pada bagian luar terdapat lapisan tipls seperti kerak. Patina Inl terbentuk karena hasll pengendapan partikelpartikel halus darı tanah yang kemudian terjadı senyawa dam akhirnya mèlekat pada dinding kreweng. Patina melekat pada seluruh baglan kreweng balk pada baglan dorsal, ventral. maupun pada baglan lalnnya.

Ketiga clrı gerabah kuna di atas belum dapat dijadikan pedoman yang mantap untuk menentukan kekunaan gerabah. mengingat bahwa ketiga clri itu dapat terjadi pada gerabah resen dan baru sehingga dapat terjadi kekeliruan dalam menentukan kekunaannya. Agar penentuan tingkat kekunaan gerabah lebih mantap, ketiga clri itu masth perlu dipadukan dengan beberapa cara pengumpulan data. misalnya wawancara. dan pengamatan stratigraf. Wawancara dilakukan sebelum penelitian dimulal sedangkan pengamatan stratigraf dilakukan ketika penelitian berlangsung.

Keempat wawancara dilakukan kepada beberapa orang tua tentang kondisi situs yang akan diteliti. Apablla situs yang bersangkutan pernah dijadikan lahan perrnukiman, maka dalam menentukan kekunaan gerabah harus berhatj-hats. karena di daerah bekas pernnuklman ini sering terjadi percampuran gerabah antara gerabah kuna, resen. dan banu. Gerabah kuna berasal dart masa permukman jauh sebelumnya, gerabah resen dapat terjadi dari pernukdman sebelum permukdman sekarang, dan gerabah baru 
berasal dart permuldman yang masth berlangsung, bercampur menjadi satu saat terjadı permukiman yang terakhlr.

Dalam wawancara fuga harus ditanyakan tentang adanya kegiatan pertanian dan ekonoml yang permah terjadi di situs itu karena pada keglatan Inl sering terjadi pemtndahan kreweng yang lebth muda. Pupuk yang berasal dart lingkungan perumahan penduduk sering bercampur dengan kreweng di sekttamya. Kemudian pupuk ini diangkut dan akhimya disebarkan di seluruh lahan pertanian (Bennet Bronson dan Teguh Asmar, 1973). Selaln itu pondok yang didirtkan di tepl lahan pertanian, sering berkembang menjadi permukiman sementara dan berfungsi untuk tempat istirahat dan menjaga tanaman. Kehidupan sementara yang terjadi di pondok itu tidak dapat diplsahkan darl pemakalan gerabah.

Keglatan ritual yang pernah terjadi atau maslh berlangsung di suatu tempat mungkin telah berlangsung lama. Dalam kegiatan ritual Ini Juga tidak dapat dipisahkan dart penggunaan gerabah sehingga gerabah kuna dapat bercampur dengan gerabah yang leblh mucia. Wawancara untuk mendapatkan Informasl tentang kondisi tempat ritual InI perli: dilakukan agar dapat dilakukan pemisahan antara tingkat kekunaan gerabah tersebut dapat dilakukan dengan baik.

Kelima pengamatan stratigrafi, telah diketahul bahwa lapisan tanah di bagian bawah berumur le bih tua daripada lapisan tanah di atasnya. Dart laplsan tanah yang belum terganggu semua gerabah yang ditemukan dapat diandalkan tingkat kekunaanya, mesklpun gerabah itu mempunyal varlasl yang beraneka bentuk dan tipe. Sebaliknya apablla gerabah ditemukan dari lapisan tanah yang telah terganggu (disturbed), penentuan tingkat kekunaan gerabah masth tetap meragukan.

\section{II}

Cara-cara penentuan tingkat kekunaan gerabah di atas pada umumnya sudah cukup, tetapl masth terdapat keraguar. Keraguan Ini terutama muncul bag: penelitl yang baru tertark pada gerabah. Bagl penelt ṫ yang telah zering mengenall gerabah caracara tersebut baru menupakan cara sementara yang perlu dilakukan di lapangan. apablla keadaan mendesak. Cara pating praktis dan 
dapat dilakukan oleh beberapa tingkatan penelitı adalah jengan membuat referenst Pembuatan referensi memakan waktu lama sehingga identifleast tentang kekunaan gerabah tidak dapat dilakukan dalam waktu cepat sebelum referensl dapat diselesalkan.

Referensi perlu dibuat karena tingkat kekunaan gerabah di situs yang satu dengan situs lalnnya tidak sama. Referensi yang dibuat untuk satu situs tidak selalu dapat diterapkan sebagal bahan acuan untuk situs lain. Dengan demiklan setlap penelitian situs bani harus dibuat referensi.

Meskipun demlklan referensl gerabah kuna yang disusun darl suatu situs yang mempunyal banyak varlasi gerabah kuna mungkin dapat diterapkan pada situs bin.

Referensi harus dibuat dengan mengumpulkan beberapa kereweng, balk kuna, resen, maupun kereweng bari. Krewengkreweng yang dijadlkan sampel itu harus diambil darl situs setempat atau lingkungan situs terdekat. Apablla tidak ditemukan sampel dart situs setempat, pengambllan sampel dapat dilakukan darl lingkungan situs terdekat, bahkan sampel dapat diambil pula dari daerah yang leblh Jauh dart situs itu bila situs dan lingkungannya tidak mampii membertkan sampel yang memadal.

Gerabah kuna yang ditemukan darl situs yang ditelith dapat dijadikan acuan, asal gerabah itu mempunyal konteks dengan temuan laln. misalnya berhubungan dengan penguburan. Gerabah sebagal acuan jenls Inl sangat terbatas aplikasinya karena tkak dapat dipergunakan untuk menentukan kekunaan gerabah jenis laln yang memillki cirl berbeda. Akan tetapl blla kondisl situsnya belum terganggu, maka sebaglan besar kreweng yang ditemukan dapat dianggap kuna. Lebth-lebth didukung oleh stratigrafl yang masth asli.

Masalah yang leblh rumit akan dihadapl blla dari penelitian ditemukan berbagal jenls kreweng yang berasal dart stratigraf yang sudah teraduk. Dalam menghadapl masalah inl sampel referensl harus diambll dart lingkungan situs setempat atau darl daerah yang leblh jauh. Sampel-sampel itu dapat diperoleh dart koleksl temuan Kantor Departemen Pendidikan dan Kebudayaan setempat atau dar Museum Wilayah dan bahkan dapat dicarl dart Museum Pusat apabila dianggap perlu.

Apablla sampel yang dirnaksudkan telah lengkap. tundakan selanjutnya lalah mensejajarkan sampel-sampel itu satu sams laln. Kumpulan sampel kreweng kuna diletakkan dalam satu deret, 
kemudian sampel kreweng resen dan baru diletakkan pada deretan laln. Kemudian kreweng hasll penelitian yang masth diragukan kekunaannya, satu deml eatu atau kelompok deml kelompok dibandingkan.

Darl hasil perbandingan itu kemudian dapat ditentukan dengan mudah tingkat kekunaan kreweng hasil penelitian itu berdasarkan persamaan cirl yang ada pada referensl itu. Tentu saja blla diperoleh ketentuan bahwa kreweng hasll penelitian ternyata kuna, maka segera dladakan perlakuan sesual dengan prosedur Akan tetapl blla terdapat tiga kelompok ciri, yaltu kuna, resen, dan baru. maka kedua kreweng terakhir inl masth perlu dipertimbangkan, apakah dibuang atau tetap disimpan. 


\section{metubtakan}

Binford, Lewlo R.,1962. Archaeology as Anthropology, Amertean Anthropoloro. 28.

Bronson. Bennet, et.al. 1973. Laporan Penelitian Arkeolod d Sumatera, LPPN - The Untversity of Pennsytvanla, Museum.

Bronson. Bennet dan Teguh Asmar. 1973. Laporan Penelitian Arkeologs ds Ratis Baka, LPPN - The Untversity of Pennsylvanla Museum.

Childe, V.G. 1956. A Short Introduction to Archaeolors. Frederlck Muller Ltd. London.

Goenadi. Nh. 1980. Sebuah Catatan Tambahan tentang Prehtstort Irlan Jaya. Serf Penerbitan Balad Arkeologl Fogyakerta Nomor I,

1988. Pembuatan Gerabah Tradisional di Pulau Bawean Berkala Arkeologi IX (1).

Hiarlej. Wanda M. 1984. Tradist Pembuatan Gerabah di Daerah Moluku. Toede Sarjana Fakultas Sastra UGM.

Mundardjito, 1984. Pardargan Tafonoml dalam Arkeologi: Perllalan Kemball atas Teort dan Metode. Pertemuan Mmiab Arkeologi II.

Nies Anggraent. 1982. Peningggalan-peninggalan Prasejarah di Sektar Danau Cangkuang (Leles), Relpataru 2.

Norton, FH. 1956. Ceramic for the Artfet Potter. Addison Wasley Publishing Company.

Samidi. 1982. Penyelamatan Temuan Tembikar Selama Ekskavast, Majalah Arkeologi TH. V No. 2..

Schiffer, MB 1976.. Behaviora Archaoology. Academic Press: New York.,

Sharer, RJ and Wendy Aohmore., Pundamentals of Archaeolon. The Benjamin / Cumming Company, inc.: California, 1979.

Solhelm II, WG. 1964Pottery and The Malaya-Polynesians, Current Anthropolocy 5(5).

Sumijat AS. 1983 .Tradist Pembuatan Gerabah di Nualela. Pulau Lomblen. Flores Tunw (Suatu Tradisi Teknologi Masa Beroocok Tanawn. Portemunn Mminh Arkoolod III. 


\section{Bagan Ponentunn Tlo.that Eokmnann Gorabah}

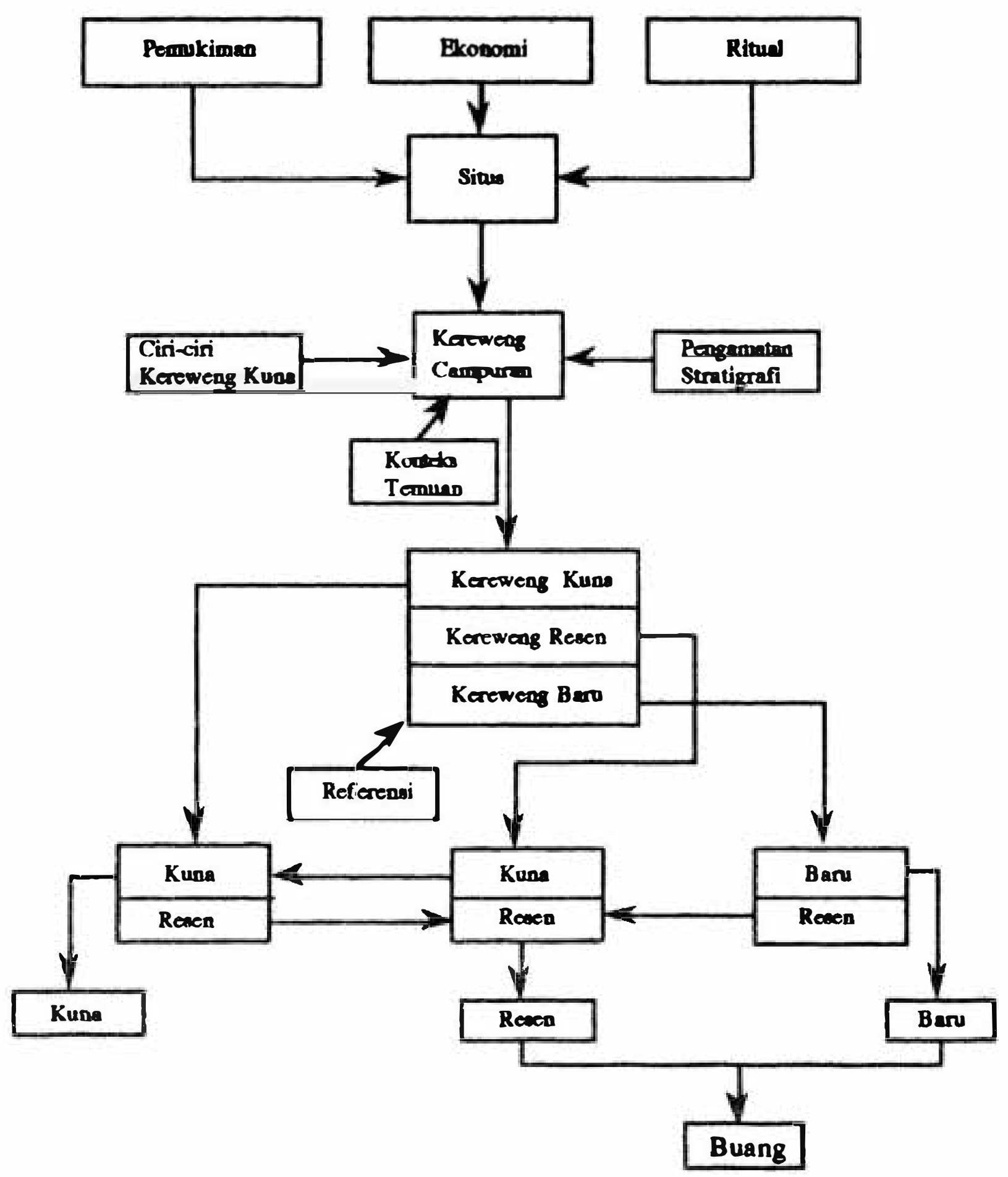

